\title{
In Vitro Characterization of the Effects of MCl-154, a Novel Cardiotonic Agent, on Cardiac Tissues
}

\author{
Akihiro NARIMATSU, Yoshimi KITADA*, Naoya SATOH, Miyuki MORITA, \\ Akiko MUROYAMA ${ }^{1}$, Masaki KOBAYASHI ${ }^{1}$ and Yasushi OHIZUMI ${ }^{1}$ \\ Pharmaceuticals Laboratory, Research Center, Mitsubishi Kasei Corporation, \\ 1000 Kamoshida-cho. Midori-ku. Yokohama 227, Japan \\ 'Mitsubishi-Kasei Institute of Life Sciences, 11 Minamiooya, Machida. Tokyo 194. Japan
}

Accepted December 9, 1988

\begin{abstract}
In vitro cardiac effects of a cardiotonic drug, $\mathrm{MCl}-154$, for which the main action mechanism was proposed to be the enhancement of $\mathrm{Ca}^{2+}$ sensitivity of cardiac contractile proteins, were investigated. $\mathrm{MCl}-154\left(3 \times 10^{-8}-3 \times 10^{-4} \mathrm{M}\right)$ increased the developed tension in isolated ventricular muscles from cats, dogs, guinea pigs and rats and increased that of isolated left atrial muscles of guinea pigs and rats. However, species differences were observed in the responses to $\mathrm{MCl}$ 154. The positive inotropic potency of $\mathrm{MCl}-154$ was stronger than those of amrinone and milrinone. In the isolated right atria from guinea pigs and rats, properties of the chronotropic effect of $\mathrm{MCl}-154$ were different from those of amrinone and milrinone. The positive inotropic action of $\mathrm{MCl}-154$ was not affected by phentolamine, propranolol, cimetidine and tetrodotoxin. $\mathrm{MCl}-154$ did not inhibit cardiac $\mathrm{Na}^{+}, \mathrm{K}^{+}$-ATPase. $\mathrm{MCl}-154$ modelately stimulated $\mathrm{Ca}^{2+}$ uptake of isolated cardiac sarcoplasmic reticulum (SR), but induced no release of $\mathrm{Ca}^{2+}$ from the SR. These results support the view that the main mechanism for the action of $\mathrm{MCl}-154$ is the enhancement of $\mathrm{Ca}^{2+}$ sensitivity of cardiac contractile proteins.
\end{abstract}

$\mathrm{MCl}-154,6-\left[4-\left(4^{\prime}-\right.\right.$ pyridyl $^{2}$ aminophenyl] 4,5-dihydro-3 $(2 \mathrm{H})$-pyridazinone hydrochloride is a novel cardiotonic agent (1-4) with a vasodilator property (2-7). We and Satoh et al. have shown that $\mathrm{MCl}-154 \mathrm{im}$ proved cardiac performance in animal heart failure models $(4,8)$. Direct positive inotropic effects of $\mathrm{MCl}-154$ on isolated cardiac muscles were demonstrated in ventricular muscles of dogs (9) and guinea pigs (10). However, inotropic effects of the agent on the ventricular muscles of other animals species and chronotropic effects on spontaneously beating right atria have not been examined. Such examinations are important to compare the pharmacological profile of $\mathrm{MCl}-154$ with those of new cardiotonic agents such as amrinone and milrinone, since species difference in the inotropic response and the

* To whom correspondence should be addressed. direct positive chronotropic response to these agents have been reported (11-13).

Concerning the mechanisms responsible for the cardiotonic action of $\mathrm{MCl}-154$, we have reported that 1) $\mathrm{MCl}-154$ increased the $\mathrm{Ca}^{2+}$ sensitivity of the contractile protein svstem in the skinned cardiac muscle of the guinea pig $(14,15), 2) \mathrm{MCl}-154$ exerted little effect on the crude phosphodiesterase of the canine heart (9), and 3) $\mathrm{MCl}-154$ did not increase significantly cyclic AMP content in the dog heart (9). These results suggest that the $\mathrm{Ca}^{2+}$-sensitivity increasing effect may be the main mechanism for the positive inotropic action of $\mathrm{MCl}-154$. To clarify this, we have to examine other possible mechanisms because myocardial contraction is regulated by various mechanisms and many interventions can be theoretically cardiotonic $(16,17)$.

In the present study, we investigated the 
effects of $\mathrm{MCl}-154$ on isolated ventricular and atrial muscles from various animal species and examined some possible mechanisms for the action of $\mathrm{MCl}-154$ other than the enhancement of $\mathrm{Ca}^{2+}$ sensitivity of cardiac contractile proteins.

\section{Materials and Methods}

Isolated heart muscle preparations: Male Hartley guinea pigs $(250-400$ g), male Wistar rats $(350-400 \mathrm{~g})$, male Japanese white rabbits $(2-3 \mathrm{~kg})$, dogs $(6-14 \mathrm{~kg})$ and cats $(2.5-4 \mathrm{~kg})$ of either sex were used. The hearts were isolated from these animals. The right ventricular papillary muscles were dissected from the guinea pig, rat, rabbit and cat hearts. The right ventricular trabeculae were excised from the dog heart. The right and left atria were dissected from the rat and guinea pig hearts. These muscles were mounted in organ baths containing modified Krebs-Ringer solution at $32^{\circ} \mathrm{C}$ (the ventricular muscles) or $37^{\circ} \mathrm{C}$ (the atrial muscles) and bubbled with $95 \% \mathrm{O}_{2}$ and $5 \% \mathrm{CO}_{2}$. The solution had the following composition: $120.3 \mathrm{mM} \mathrm{NaCl}, 4.8$ $\mathrm{mM} \mathrm{KCl}, 1.8 \mathrm{mM} \mathrm{CaCl}_{2}, 1.3 \mathrm{mM} \mathrm{MgSO}_{4}, 1.2$ $\mathrm{mM} \mathrm{KH}_{2} \mathrm{PO}_{4}, 1.2 \mathrm{mM} \mathrm{NaHCO}_{3}$ and $5.5 \mathrm{mM}$ glucose. The guinea pig, rat, cat and dog ventricular muscles and the guinea pig atria were stretched with a resting tension of $0.5 \mathrm{~g}$ and the rabbit papillary muscles, with $0.8 \mathrm{~g}$. The ventricular muscles and left atria were stimulated at 1 and $2 \mathrm{~Hz}$, respectively, with rectangular pulses of $1.2 \times$ threshold voltage and $1 \mathrm{msec}$ duration. Contractile force of the cardiac muscles was measured by a forcedisplacement transducer (Nihon Kohden, TB612T and Minebea Co. Ltd., UL-2GR) and recorded on a rectilinear recorder (NEC Sanei, 8K-23). Spontaneously beating rate of the right atria was counted with a cardiotachometer triggered by pulses of the contraction and recorded on a rectilinear recorder. After 60 min equilibration time, drugs were cumulatively added into the organ baths. When the influence of various blockers on the action of $\mathrm{MCl}-154$ was examined, the inotropic effect of $\mathrm{MCl}-154$ was expressed as the percentage fraction of the maximum effect induced by isoproterenol in the same preparation in order to eliminate the interindividual variability in the response to $\mathrm{MCl}-154$.
$\mathrm{Na}^{+}, \mathrm{K}^{+}$-ATPase assay: $\mathrm{Na}^{+}, \mathrm{K}^{+}$-ATPase was prepared from the guinea pig myocardium by the method of Pitts and Schwartz (18). After $5 \mathrm{~min}$ pretreatment with the enzyme, reaction was carried out at $37^{\circ} \mathrm{C}$ for $15 \mathrm{~min}$ in $0.5 \mathrm{ml}$ of a reaction mixture that contained $100 \mathrm{mM} \mathrm{NaCl}, 20 \mathrm{mM} \mathrm{KCl}, 5 \mathrm{mM} \mathrm{MgCl}$. $3 \mathrm{mM}$ ATP and $50 \mathrm{mM}$ Tris- $\mathrm{HCl}(\mathrm{pH} 7.4)$. The reaction procedure was the same as described by Ohizumi and Yasumoto (19).

$\mathrm{Ca}^{2+}$-pumping and $\mathrm{Ca}^{2+}$-releasing activities of fragmented sarcoplasmic reticulum (SR) of the heart muscle: Cardiac SR was isolated from the dog heart by the method of Harigaya and Schwartz (20). $\mathrm{Ca}^{2+}$-pumping activity of the SR was measured according to the method of Nakamura et al. (21) and Kobayashi et al. (22). Briefly, the SR (1.5 mg/ $\mathrm{ml})$ was suspended in an assay mixture (final volume, $1 \mathrm{ml}$ ) containing $0.05 \mathrm{mM} \mathrm{CaCl}_{2}, 90$ $\mathrm{mM} \mathrm{KCl}, 3 \mathrm{mM} \mathrm{MgCl}_{2}, 2 \mathrm{mM} \mathrm{NaN}_{3}, 5 \mathrm{mM}$ creatine phosphate and $50 \mathrm{mM}$ Mops- $\mathrm{KOH}$ buffer ( $\mathrm{pH} \mathrm{7.0)}$ at $30^{\circ} \mathrm{C}$. $\mathrm{Ca}^{2+}$ concentration in the mixture was monitored with a $\mathrm{Ca}^{2+}$ electrode $(21,22)$. The reaction of $\mathrm{Ca}^{2+}$ uptake was started by adding ATP and creatine kinase (final concentrations were 1 $\mathrm{mM}$ and $0.1 \mathrm{mg} / \mathrm{ml}$, respectively). $\mathrm{Ca}^{2+}$ releasing action of the drugs was examined by adding the drugs to the reaction mixture when the $\mathrm{Ca}^{2+}$ concentration of the mixture was reduced to submicromolar level.

SR $\mathrm{Ca}^{2+}$-ATPase assay: According to the method of Kobayashi et al. (22), SR Ca ${ }^{2+}$ ATPase was prepared from the dog heart muscle and the enzyme activity was measured.

Drugs: $\mathrm{MCl}-154$, amrinone and milrinone were synthesized at our Research Center. Other drugs used were as follows: phentolamine mesylate (Regitin ${ }^{\circledR}$, Ciba-Geigy), propranolol hydrochloride (Sigma), cimetidine (Fujisawa Pharmaceutical Co.), tetrodotoxin (Sankyo Pharmaceutical Co.), ouabain (Tokyo Kasei) and caffeine (Wako Pure Chemical).

$\mathrm{MCl}-154$, propranolol, tetrodotoxin, ouabain and caffeine were dissolved in $0.9 \%$ $\mathrm{NaCl}$ solution. Cimetidine was dissolved in $0.1 \mathrm{~N} \mathrm{HCl}$. Amrinone and milrinone were dissolved in $0.05 \mathrm{~N}$ lactic acid and $0.05 \mathrm{~N} \mathrm{HCl}$, respectively. Phentolamine was supplied in 
ampoules. These drug solutions were diluted with $0.9 \% \mathrm{NaCl}$ solution when necessary.

Statistical analysis: The results are expressed as means \pm S.E.M. The statistical analysis of effects of $\mathrm{MCl}-154$ was carried out using Student's $t$-test. Two-way analysis of variance was used to determine the significance of difference between blocker-treated and non-treated groups. A value of $P<0.05$ was considered to indicate significance.

\section{Results}

Effects of $\mathrm{MCl}-154$ on developed tension of isolated ventricular muscles from various animal species and isolated left atria guinea pigs and rats: $\mathrm{MCl}-154\left(3 \times 10^{-8}-3 \times 10^{-4} \mathrm{M}\right)$ increased developed tension of cat, dog. guinea pig and rabbit ventricular muscles in a concentration-dependent manner (Fig. 1A). However, there was some species difference in the positive inotropic effects of $\mathrm{MCl}-154$ as indicated by $\mathrm{EC} 50 \%$ (concentration for increasing developed tension by $50 \%$ ). The approximate EC50\% values in cat, dog. guinea pig and rabbit ventricular muscles were $11,0.44,0.95$ and $2.1 \mu \mathrm{M}$, respectively. Although $\mathrm{MCl}-154$ also increased significantly the developed tension of rat papillary muscle. the sensitivity of the rat muscles to $\mathrm{MCl}-154$ was much less than those of other species, and the increase in developed tension of the rat ventricular muscle did not reach $50 \%$ even at the highest concentration $\left(3 \times 10^{-4} \mathrm{M}\right)$.

On the left atria of guinea pigs and rats, $\mathrm{MCl}-154$ also exerted a concentration-dependent positive inotropic effect (Fig. 1B). At $3 \times 10^{-4} \mathrm{M}$ the increase in developed tension of the rat left atria (80.6\%) was more than that of the rat papillary muscles $(19.7 \%$, Fig. 1A). Nevertheless, the sensitivity of the rat atria to $\mathrm{MCl}-154$ was much less than that of guinea pig atria (Fig. 1B).

Comparison of inotropic and chronotropic effects of $\mathrm{MCl}-154$ on isolated cardiac tissues from guinea pigs and rats with those of amrinone and milrinone: In the guinea pig papillary muscle preparations, $\mathrm{MCl}-154$ (3× $\left.10^{-8}-3 \times 10^{-4} \mathrm{M}\right)$, amrinone $\left(3 \times 10^{-6}-10^{-3} \mathrm{M}\right)$ and milrinone $\left(10^{-7}-3 \times 10^{-4} \mathrm{M}\right)$ increased developed tension in a concentration dependent manner (Fig. 2A). Approximate EC50\% of $\mathrm{MCl}-154$, amrinone and milrinone
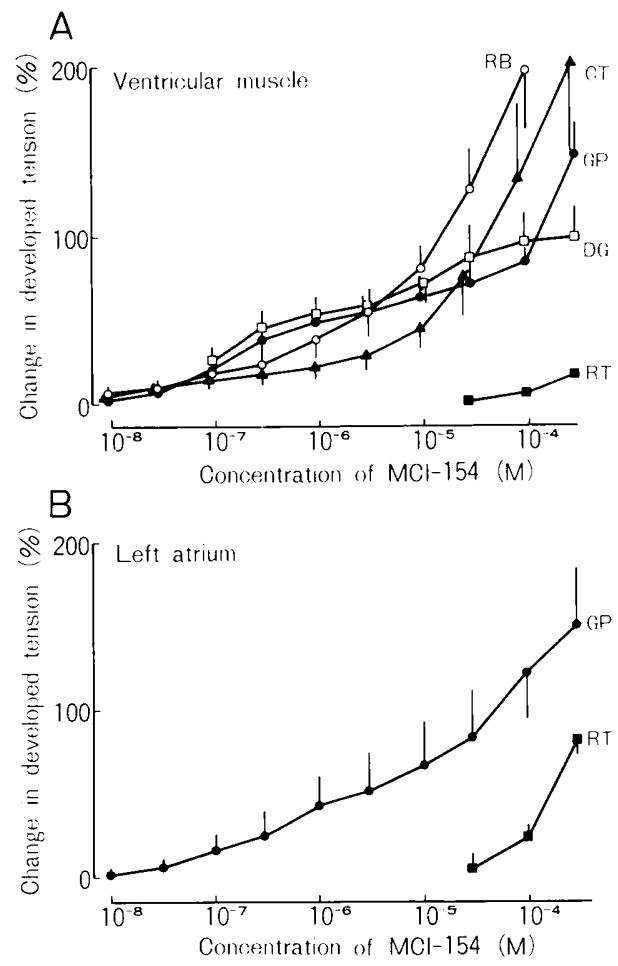

Fig. 1. Concentration-response curves for the positive inotropic effects of $\mathrm{MCl}-154$ on isolated ventricular and atrial muscles from various animal species. A: The effects on isolated papillary muscles of cats (CT. $\Delta, n=6$ ), guinea pigs ( $G P, O, n=16$ ), rabbits ( $R B$. $\bigcirc, n=5)$ and rats (RT, $\square, n=5)$, and on isolated trabeculae of dogs ( $D G, \square, n=6$ ). Basal contractile forces for the cat, guinea pig, rabbit, rat and dog ventricular muscles were $581 \pm 122,174 \pm 21,265 \pm$ $49,449 \pm 90$ and $605 \pm 203 \mathrm{mg}$, respectively. B: The effects on isolated left atria of guinea pigs (GP. $n=9)$ and rats (RT, $\square, n=5)$. Basal contractile forces of the guinea pig and rat atria were $588 \pm 62$ and $337 \pm 29 \mathrm{mg}$, respectively.

were $0.95,558$ and $6.6 \mu \mathrm{M}$, respectively. $\mathrm{MCl}-154$ was about 590 and 7 times as potent as amrinone and milrinone, respectively. In the rat papillary muscle preparations, MCl-154 (above $10^{-4} \mathrm{M}$ ) produced the increase in developed tension as mentioned above (Figs. $1 \mathrm{~A}$ and $3 \mathrm{~A}$ ). However, milrinone up to $3 \times 10^{-4} \mathrm{M}$ did not increase developed tension in these preparations, and even decreased it at higher concentrations (Fig. 3A).

Chronotropic effects of $\mathrm{MCl}-154$, amrinone and milrinone on spontaneously beating right 
A
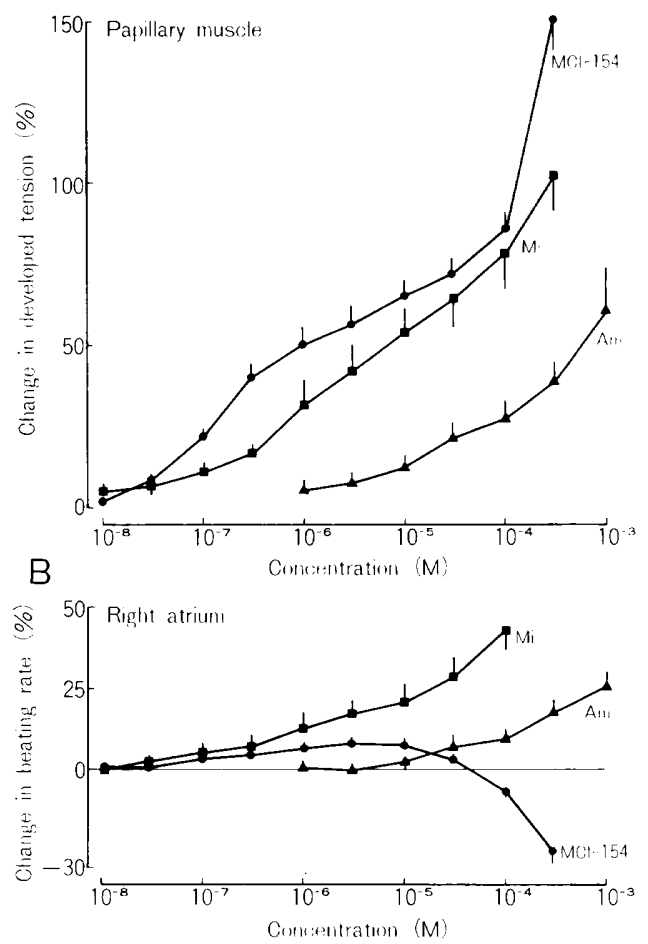

Fig. 2. Comparison of the inotropic and chronotropic responses of isolated guinea pig cardiac muscles to $\mathrm{MCl}-154$ with those to amrinone and milrinone. $A$ : The positive inotropic responses of isolated guinea pig papillary muscles to $\mathrm{MCl}-154$ (O, $n=16)$, amrinone (Am, $\boldsymbol{\Delta}, n=8)$ and milrinone (Mi, $\boldsymbol{\square}, n=7$ ). Basal contractile forces for $\mathrm{MCl}-154$, amrinone and milrinone were $174 \pm 21,176 \pm 42$ and $193 \pm 30 \mathrm{mg}$. respectively. $B$ : The chronotropic responses of isolated spontaneously beating right atria of the guinea pig to $\mathrm{MCl}-154$ (O, $n=13$ ), amrinone (Am, $\boldsymbol{\Lambda}, n=6$ ) and milrinone ( $\mathrm{Mi}, \mathbf{\square}, \mathrm{n}=6$ ). Basal beating rates for $\mathrm{MCl}-154$, amrinone and milrinone were $223 \pm 9$. $207 \pm 6$ and $199 \pm 11 \mathrm{bpm}$, respectively.

atria of guinea pigs are shown in Fig. 2B. Amrinone $\left(10^{-5}-10^{-3} \mathrm{M}\right)$ and milrinone $\left(10^{-7}-10^{-4} \mathrm{M}\right)$ increased beating rate in a concentration-related manner. In contrast with this, the concentration-response curve of $\mathrm{MCl}-154$ was bell-shaped; i.e., $\mathrm{MCl}-154$ caused a modelate increase in atrial rate in the concentration range of $10^{-7}-3 \times 10^{-5} \mathrm{M}$ but caused a decrease in the rate at higher concentrations $\left(10^{-4}-3 \times 10^{-4} \mathrm{M}\right)$ (Fig. 2B). In the right atrium preparations of rats, $\mathrm{MCl}$ -
A

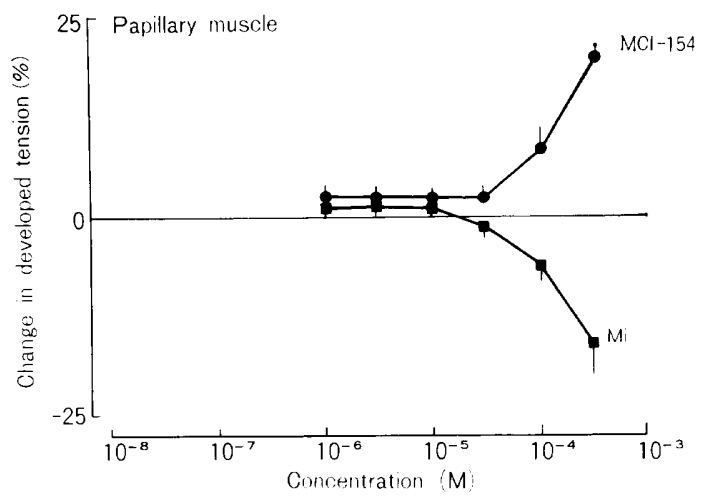

B

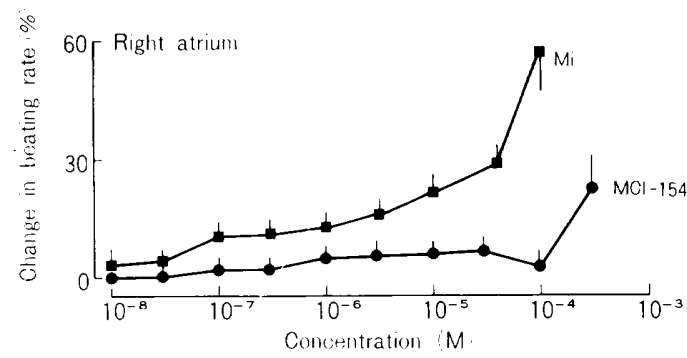

Fig. 3. Comparison of the inotropic and chronotropic responses of isolated rat cardiac muscles to $\mathrm{MCl}-154$ with those to milrinone. $\mathrm{A}$ : The inotropic responses of isolated rat papillary muscles to $\mathrm{MCl}-154$ (O. $n=5$ ) and milrinone ( $\mathrm{Mi}, \mathbf{\square}, \mathrm{n}=6$ ). Basal contractile forces for $\mathrm{MCl}-154$ and milrinone were $449 \pm 90$ and $558 \pm 117 \mathrm{mg}$, respectively. B: The chronotropic response of isolated spontaneously beating right atria of the rat to $\mathrm{MCl}-154$ (O. $n=5$ ) and milrinone (Mi, $\square, n=4$ ). Basal beating rates for $\mathrm{MCl}-154$ and milrinone were $236 \pm 27$ and $261 \pm 7$ bpm, respectively.

154 produced only little or no increase in the beating rate up to $10^{-4} \mathrm{M}$ and produced a moderate increase at $3 \times 10^{-4} \mathrm{M}$ (Fig. 3B). In contrast with $\mathrm{MCl}-154$, milrinone (above $3 \times 10^{-8} \mathrm{M}$ ) increased the beating rate in a concentration-dependent manner (Fig. 3B).

Effects of receptor or channel blockers on the positive inotropic response of isolated guinea pig papillary muscles to $\mathrm{MCl}-154$ : Phentolamine $\left(10^{-6} \mathrm{M}\right)$, propranolol $\left(10^{-6}\right.$ $\mathrm{M})$, cimetidine $\left(10^{-5} \mathrm{M}\right)$ and tetrodotoxin $\left(10^{-5} \mathrm{M}\right)$ did not significantly modify the positive inotropic effect of $\mathrm{MCl}-154$ (Fig. 4).

Effect on cardiac $\mathrm{Na}^{+}, \mathrm{K}^{+}$-ATPase: $\mathrm{MCl}$ 154 in the concentration range of $10^{-6}$ to 


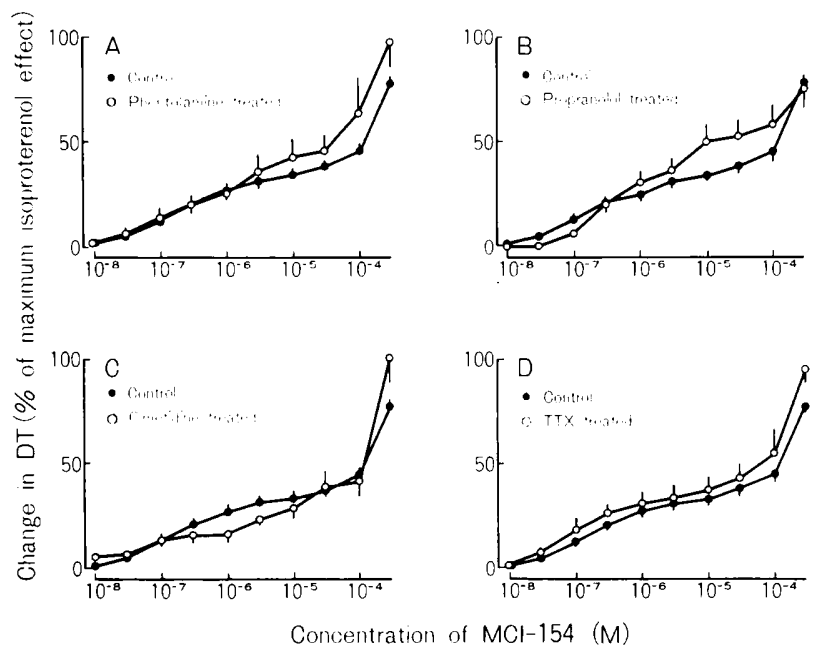

Fig. 4. Effects of (A) phentolamine $\left(10^{-6} M, n=5\right),(B)$ propranolol $\left(10^{-6} M, n=6\right),(C)$ cimetidine $\left(10^{-5} M, n=6\right)$ and $(D)$ tetrodotoxin (TTX, $\left.10^{-5} M, n=5\right)$ on the positive inotropic response of isolated papillary muscles of guinea pigs to $\mathrm{MCl}-154(n=11$ for control). Changes in developed tension (DT) were expressed as the percentage fraction of the maximum effect induced by isoproterenol in the same preparation. Basal contractile force and maximal response to isoproterenol were $221 \pm 36$ and $321 \pm 33$ $\mathrm{mg}(\mathrm{n}=33)$, respectively.

Table 1. Effects of $\mathrm{MCl}-154$ and ouabain on $\mathrm{Na}^{+}, \mathrm{K}^{+}$-ATPase of the guinea pig myocardium

\begin{tabular}{ccc}
\hline Drug & Conc. $(\mathrm{M})$ & \% change in activity \\
\hline MCl-154 & $10^{-6}$ & -3.8 \\
& $10^{-5}$ & -1.4 \\
Ouabain & $10^{-4}$ & -2.7 \\
\hline
\end{tabular}

Each value represents the mean of two determinations.

$10^{-4} \mathrm{M}$ exerted almost no effect on the cardiac $\mathrm{Na}^{+}, \mathrm{K}^{+}$-ATPase of the guinea pig (Table 1). Ouabain $\left(10^{-4} \mathrm{M}\right)$ completely inhibited this enzyme (Table 1).

Effects of $\mathrm{MCl}-154$ on pumping and releasing of $\mathrm{Ca}^{2+}$ by fragmented $\mathrm{SR}$ of the canine myocardium: The $\mathrm{Ca}^{2+}$-pumping activity of fragmented $\mathrm{SR}$ could be observed by directly measuring extravesicular $\mathrm{Ca}^{2+}$ concentration with a $\mathrm{Ca}^{2+}$ electrode (Fig. 5). Immediately after the addition of ATP, free $\mathrm{Ca}^{2+}$ concentration decreased rapidly due to the formation of $\mathrm{Ca}^{2+}$-ATP complexes and further decreased gradually due to the active $\mathrm{Ca}^{2+}$ uptake by the fragmented myocardial SR. The profile of net $\mathrm{Ca}^{2+}$ uptake exhibited a biphasic time course (slow and fast phases). The slow-uptake phase continued 2-3 min and was followed by the fast-uptake phase.
$\mathrm{Ca}^{2+}$ uptake became slower when fragmented $\mathrm{SR}$ had been filled with $\mathrm{Ca}^{2+}$ and the extravesicular $\mathrm{Ca}^{2+}$ concentration was reduced to submicromolar levels. Using this system. the effects of $\mathrm{MCl}-154$ was examined on $\mathrm{Ca}^{2+}$-pumping and releasing by SR. Pretreatment of $\mathrm{MCl}-154\left(10^{-7}-10^{-6} \mathrm{M}\right)$ accelerated $\mathrm{Ca}^{2+}$ uptake in a concentrationrelated manner (Fig. 5). For investigating the $\mathrm{Ca}^{2+}$ releasing effect, $\mathrm{MCl}-154\left(3 \times 10^{-5}\right.$ $\left.6 \times 10^{-5} \mathrm{M}\right)$ was administered when fragmented SR was filled with $\mathrm{Ca}^{2+}$ (Fig. 6A). No increase in extravesicular $\mathrm{Ca}^{2+}$ concentration was observed, indicating that $\mathrm{MCl}$ 154 did not release $\mathrm{Ca}^{2+}$ from the SR. On the other hand, caffeine at the concentration of $1 \mathrm{mM}$ released $\mathrm{Ca}^{2+}$ from the SR (Fig. 6B).

Effect on cardiac SR $\mathrm{Ca}^{2+}$-ATPase: $\mathrm{MCl}$ $154\left(10^{-7}-10^{-6} \mathrm{M}\right)$ moderately but sig- 


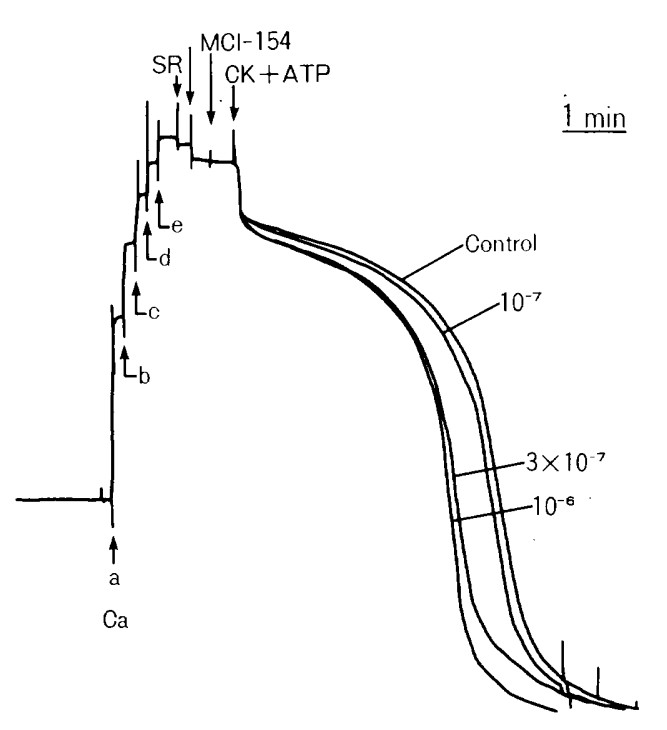

Fig. 5. Stimulatory effect of $\mathrm{MCl}-154$ on the $\mathrm{Ca}^{2+}$ pumping activity of fragmented cardiac SR. The extravesicular $\mathrm{Ca}^{2+}$ concentration in the reaction mixture was monitored with a $\mathrm{Ca}^{2+}$ electrode. At the beginning of each experiment, $10 \mu \mathrm{M} \mathrm{CaCl}_{2}$ was added stepwise, five times (a-e), as the internal standard. Then fragmented cardiac SR (SR), creatine phosphate (CP), vehicle or $\mathrm{MCl}-154$ solutions (final concentration: $10^{-7}-10^{-6} \mathrm{M}$ ) were added, and the reaction of $\mathrm{Ca}^{2+}$ uptake was started by adding simultaneously ATP and creatine kinase (CK).

A

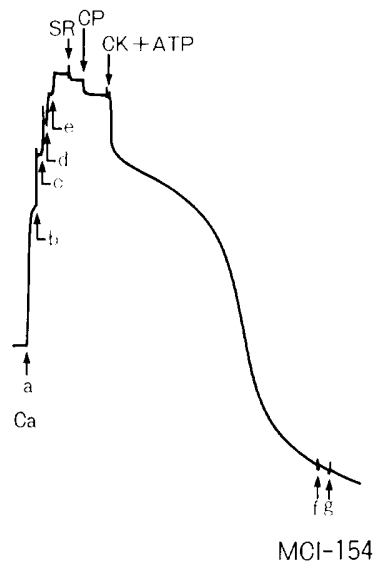

nificantly increased the SR $\mathrm{Ca}^{2+}$-ATPase activity (Table 2). However at a higher concentration $\left(10^{-5} \mathrm{M}\right)$, no significant increase in the ATPase activity was observed (Table 2).

\section{Discussion}

$\mathrm{MCl}-154$ increased developed tension in ventricular muscles isolated from cats, dogs, guinea pigs, rabbits and rats. These results indicate that $\mathrm{MCl}-154$ exerts a direct positive inotropic effect on the myocardium. However, sensitivity to $\mathrm{MCl}-154$ was somewhat different among the animal species. Such species difference in inotropic sensitivity was also observed for milrinone in the present study and has also been reported for other cardiotonic drugs such as amrinone and OPC- -8212 (13). Especially, the sensitivity to milrinone of rat ventricular muscles was very low, and no increase in developed tension was observed in the present experiment. On the contrary, $\mathrm{MCl}-154$ significantly increased the developed tention of rat ventricular and atrial muscles even though the sensitivity of the rat cardiac muscles to $\mathrm{MCl}-154$ was lower than that of other animal species. In this respect, $\mathrm{MCl}-154$ is different from amrinone, milrinone and OPC-8212.

In the comparative study, it was revealed that the positive inotropic potency of $\mathrm{MCl}$ -

B

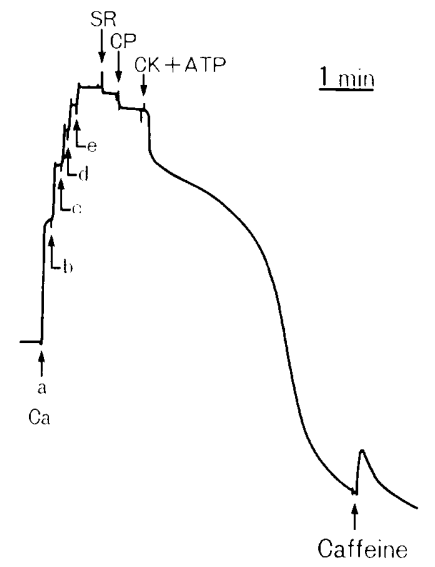

Fig. 6. Effects of $3 \times 10^{-5}$ and $6 \times 10^{-5} \mathrm{M}$ ( $\mathrm{f}$ and g, respectively) $\mathrm{MCl}-154$ (A) and of $1 \mathrm{mM}$ caffeine (B) on $\mathrm{Ca}^{2+}$ pre-loaded in the fragmented cardiac $\mathrm{SR}$ by the ATP dependent $\mathrm{C}^{2+}$-pump. Other abbreviations are the same as in Fig. 5. 
Table 2. Effect of $\mathrm{MCl}-154$ on SR $\mathrm{Ca}^{2+}$-ATPase of the dog heart muscle

\begin{tabular}{cc}
\hline Concentration of $\mathrm{MCl}-154(\mathrm{M})$ & \% change in activity \\
\hline $10^{-8}$ & $1.4 \pm 0.8$ \\
$10^{-7}$ & $10.1 \pm 2.6^{*}$ \\
$10^{-6}$ & $15.6 \pm 3.0^{*}$ \\
$10^{-5}$ & $4.0 \pm 2.9$ \\
\hline
\end{tabular}

Each value represents the mean \pm S.E.M. $(n=4) . \quad{ }^{*} P<0.05$.

154 in guinea pig papillary muscle preparations was higher than those of typical non-catecholamine, non-cardiac glycoside cardiotonic drugs, amrinone and milrinone. The order of the potencies of these drugs was the same as that obtained after i.v. injection in anesthetized dogs (4).

In the right atrial preparations, a relevant contrast was observed between the chronotropic effect of $\mathrm{MCl}-154$ and those of amrinone and milrinone. The concentrationresponse of the guinea pig atria to $\mathrm{MCl}-154$ was biphasic, a slight increase in beating rate at lower concentrations and a decrease at higher ones. On the other hand, only a concentration-dependent increase in the rate was produced by amrinone and milrinone. In the right atrium preparations of the rat. $\mathrm{MCl}$ 154 (up to $10^{-4} \mathrm{M}$ ) produced only a small increase in beating rate. However, $\mathrm{MCl}-154$ at $3 \times 10^{-4} \mathrm{M}$ increased the rate, which contrasts with the results in the guinea pig preparations that showed a negative chronotropic response to this drug. The mechanism by which such a difference in the responses of the both species to the high doses of $\mathrm{MCl}-154$ was caused remains unknown presently. In contrast with $\mathrm{MCl}-154$, milrinone increased dose-dependently the rat atrial rate. These chronotropic properties of $\mathrm{MCl}-154$ may be beneficial in the treatment of heart failure. In whole animal experiments, it has been shown that $\mathrm{MCl}-154$ caused a relatively small increase in heart rate in comparison with its potent positive inotropic effect (4).

As cardiac contraction is regulated by various mechanisms, one can increase cardiac contractility by the intervention of some of the mechanisms $(16,17)$. Stimulations of adrenergic alpha, beta and histamine 2 receptors and of sodium channels cause an increase in cardiac contractility. The present results obtained by using the blockers at appropriate concentrations $(13,23)$ ruled out such possibilities for $\mathrm{MCl}-154$. $\mathrm{MCl}-154$ did not inhibit $\mathrm{Na}^{+}, \mathrm{K}^{+}$-ATPase, indicating that the cardiac glycoside-like mechanism can be excluded.

SR can be a site of action of positive inotropic agents. For example, caffeine increases cardiac contraction by releasing $\mathrm{Ca}^{2+}$ from SR (24); and gingerol, a recently found cardiotonic agent, exerts its action by a mechanism involving direct stimulation of the $\mathrm{Ca}^{2+}$ pumping activity of $\mathrm{SR}(22,25)$. Therefore, we investigated the effects of $\mathrm{MCl}-154$ on $\mathrm{Ca}^{2+}$ pumping activity of the isolated $\mathrm{SR}$ and on $\mathrm{Ca}^{2+}$ release from the $\mathrm{SR}$. $\mathrm{MCl}-154$ somewhat stimulated the $\mathrm{Ca}^{2+}$ pumping activity, which is probably due to the enhancement of SR $\mathrm{Ca}^{2+}$-ATPase activity as demonstrated in the present experiment. $\mathrm{MCl}-154$ did not induce $\mathrm{Ca}^{2+}$ release from $\mathrm{SR}$, indicating that this agent has no caffeinelike action. These results are consistent with those obtained in cardiac skinned fibers of the guinea pig (15). Thus the stimulatory effect of $\mathrm{MCl}-154$ on SR $\mathrm{Ca}^{2+}$ uptake may be involved in the cardiotonic action of $\mathrm{MCl}$ 154. However, as the effect was relatively weak, it would not be the primary mechanism for the positive inotropic effect of the agent. The effect also provides an explanation for why relaxation time of contraction was not prolonged by $\mathrm{MCl}-154$ in spite of its increasing effect on the $\mathrm{Ca}^{2+}$ sensitivity of contractile proteins $(14,15)$. Compared with an agent like pimobendan, which is reported to increase the $\mathrm{Ca}^{2+}$ sensitivity and prolong relaxation time (23), no impairment of the relaxation by $\mathrm{MCl}-154$ would be advantageous because not only contraction but also relaxation of the heart is impaired in patients with heart failure $(26,27)$.

We have already reported that $\mathrm{MCl}-154$ inhibited less weakly the crude phos- 
phodiesterase of the canine heart than cyclic AMP phosphodiesterase inhibitors, amrinone and milrinone, and that $\mathrm{MCl}-154$ did not increase significantly cyclic AMP content in the dog myocardium, suggesting little involvement of the cyclic AMP mechanism (9). We have also demonstrated that $\mathrm{MCl}-154$ increased the $\mathrm{Ca}^{2+}$ sensitivity of the contractile protein system in the skinned cardiac muscle of the guinea pig $(14,15)$. These results together with those in the present study support the view that the main mechanism for the cardiotonic action of $\mathrm{MCl}-154$ is the enhancement of the $\mathrm{Ca}^{2+}$ sensitivity of the cardiac contractile proteins $(14,15)$.

In conclusion, the present study demonstrated the direct positive inotropic effect of $\mathrm{MCl}-154$ on the isolated ventricular muscles from various animal species. The inotropic and chronotropic effects of $\mathrm{MCl}-154$ were different from those of amrinone and milrinone in the potency and mode of action. $\mathrm{MCl}-154$ stimulated $\mathrm{Ca}^{2+}$ uptake by cardiac $\mathrm{SR}$, although the effect may not be the main action mechanism of $\mathrm{MCl}-154$. These properties of $\mathrm{MCl}-154$ differentiate this agent from other new cardiotonic drugs such as amrinone, milrinone and pimobendan.

Acknowledgment: We thank Mrs. Reiko Tsurui for her excellent technical assistance.

\section{References}

1 Okushima, H., Narimatsu, A., Kobayashi, M., Furuya, R., Tsuda, K. and Kitada, Y.: A novel class of cardiotonics. Synthesis and pharmacological properties of [4-(substituted-amino)phenyl]pyridazinones and related derivatives. J. Med. Chem. 30, 1157-1161 (1987)

2 Narimatsu, A., Kitada, Y., Satoh, N., Suzuki, R., Kobayashi, M. and Okushima, H.: Cardiovascular profile of $\mathrm{MCl}-154$, a novel and potent cardiotonic agent with vasodilator effect. Japan. J. Pharmacol. 40, Supp. 234P (1986)

3 Narimatsu, A., Kitada, Y., Satoh, N., Suzuki, R., Kobayashi, M. and Okushima, H.: Cardiovascular pharmacology of $\mathrm{MCl}-154$, a novel and potent cardiotonic compound with vasodilator property: Comparison with other cardiotonics. Fed. Proc. 45, 810 (1986)

4 Narimatsu, A., Kitada, Y., Satoh, N., Suzuki, R. and Okushima, H.: Cardiovascular pharmacology of 6-[4-(4'-pyridyl)aminophenyl]-4,5-dihydro$3(2 \mathrm{H})$-pyridazinone hydrochloride, a novel and potent cardiotonic agent with vasodilator properties. Arzneimittelforschung 37, 398-406 (1987)

5 Shimshak, T., Gross, G.J., Brooks, H.L. and Warltier, D.C.: Systemic and coronary hemodynamic effects of 4 cardiotonic agents in conscious, instrumented dogs. Fed. Proc. 45, 811 (1986)

6 Hosono, M. and Taira, N.: Cardiac and coronary vasodilator effects of the novel cardiotonic agent, $\mathrm{MCl}-154$, assessed in isolated, blood-perfused dog heart preparations. J. Cardiovasc. Pharmacol. 10, 692-698 (1987)

7 Shibata, S., Satake, N., Hester, R.K., Kurahashi, $K$. and Ito, M.: The mode of vasoinhibitory action of a pyridazione derivative (MCl-154), a new cardiotonic agent, on contractile responses induced by $\alpha$-adrenoceptor agonists and ${ }^{45} \mathrm{Ca}$ influx in isolated vascular smooth muscles. Eur. J. Pharmacol. 145, 113-121 (1988)

8 Satoh, K., Nunoki, K., Goto, T., Hosono, M., Hashimoto, H., Sato, Y. and Taira, N.: Improvement of pentobarbital-induced heart failure by $\mathrm{MCl}-154$, a novel and potent cardiotonic agent, in the dog heart-lung preparation. Japan. J. Pharmacol. 47, 189-195 (1988)

9 Kitada, Y., Narimatsu, A., Suzuki, R., Endoh, M. and Taira, N.: Does the positive inotropic action of a novel cardiotonic agent, $\mathrm{MCl}-154$ involve mechanisms other than cyclic AMP? J. Pharmacol. Exp. Ther. 243, 639-645 (1987)

10 Katayama, S., Narimatsu, A., Suzuki, R., lijima, T. and Taira, N.: Changes in membrane potentials and currents of ventricular cells of the guinea pig heart by a new cardiotonic drug, $\mathrm{MCl}-154$. Japan. J. Pharmacol. 44, 481-488 (1987)

11 Alousi, A.A., Farah, A.E., Lesher, G.Y. and Opalka, C.J., Jr.: Cardiotonic activity of amrinone-Win 40680 [5-amino-3,4'-bipyridin$6(1 \mathrm{H})$-one]. Circ. Res. 45, 666-677 (1979)

12 Alousi, A.A., Stankus, G.P., Stuart, J.C. and Walton, L.H.: Characterization of the cardiotonic effects of milrinone, a new and potent cardiac bipyridine, on isolated tissues from several animal species. J. Cardiovasc. Pharmacol. 5, 804-811 (1983)

13 Yamashita, S., Hosokawa, T., Kojima, M., Mori, $\mathrm{T}$. and Yabuuchi, $Y .:$ In vitro and in vivo studies of 3,4-dihydro-6-[4-(3,4-dimethoxybenzoyl)-1piperazinyl]-2(1H)-quinolinone (OPC-8212), a novel positive inotropic drug, in various animals. Arzneimittelforschung 34, 342-346 (1984)

14 Kitada, Y., Narimatsu, A., Matsumura, N. and Endo, M.: Contractile proteins: possible targets for the cardiotonic action of $\mathrm{MCl}-154$, a novel 
cardiotonic agent? Eur. J. Pharmacol. 134, 229231 (1987)

15 Kitada, Y., Narimatsu, A., Matsumura, N. and Endo, $\mathrm{M}$.: Increase in $\mathrm{Ca}^{++}$sensitivity of the contractile system by $\mathrm{MCl}-154$, a novel cardiotonic agent, in chemically skinned fibers from the guinea pig papillary muscles. J. Pharmacol. Exp. Ther. 243, 633-638 (1987)

16 Scholz, H.: Inotropic drugs and their mechanisms of action. J. Am. Coll. Cardiol. 4, 389-397 (1984)

17 Siegl, P.K.S.: Overview of cardiac inotropic mechanisms. J. Cardiovasc. Pharmacol. 8, Supp. 9, S1-S10 (1986)

18 Pitts, B.J.R. and Schwartz, A.: Improved purification and partial characterization of $\left(\mathrm{Na}^{+}\right.$. $\left.\mathrm{K}^{+}\right)$-ATPase from cardiac muscle. Biochim. Biophys. Acta 401, 184-195 (1975)

19 Ohizumi, Y. and Yasumoto, T.: Contractile response of the rabbit aorta to maitotoxin, the most potent marine toxin. J. Physiol. (Lond.) 337, 711-721 (1983)

20 Harigaya, S. and Schwartz, A.: Rate of calcium binding and uptake in normal animal and failing human cardiac muscle. Circ. Res. 25, 781-794 (1969)

21 Nakamura, Y., Kobayashi, J., Gilmore, J., Mascal, M., Rinehart, K.L., Jr., Nakamura, H. and Ohizumi, Y.: Bromo-eudistomin D, a novel inducer of calcium release from fragmented sarcoplasmic reticulum that causes contractions of skinned muscle fibers. J. Biol. Chem. 261, 4139-4142 (1986)
22 Kobayashi, M., Shoji, N. and Ohizumi, Y.: Gingerol, a novel cardiotonic agent, activates the $\mathrm{Ca}^{2+}$-pumping ATPase in skeletal and cardiac sarcoplasmic reticulum. Biochim. Biophys. Acta 903, 96-102 (1987)

23 Honerjäger, P., Heiss, A., Schäfer-Korting, M., Schönsteiner, G. and Reiter, M.: UD-CG 115- a cardiotonic pyridazinone which elevates cyclic AMP and prolongs the action potential in guineapig papillary muscle. Naunyn Schmiedebergs Arch. Pharmacol. 325, 259-269 (1984)

24 Endo, M. and Kitazawa, T.: E-C coupling studies on skinned cardiac fibers. In Biophysical Aspects of Cardiac Muscle. Edited by Morad, M., p. 307327. Academic Press, New York and London (1978)

25 Kobayashi, M., Ishida, Y., Shoji, N. and Ohizumi, Y.: Cardiotonic action of [8]-gingerol, an activator of the $\mathrm{Ca}^{++}$-pumping adenosine triphosphatase of sarcoplasmic reticulum, in guinea pig atrial muscle. J. Pharmacol. Exp. Ther. 246, 667-673 (1988)

26 Grossman, W., McLaurin, L.P. and Rolett, E.L.: Alterations in left ventricular relaxation and diastolic compliance in congestive cardiomyopathy. Cardiovasc. Res. 13, 514-522 (1979)

27 Monrad, E.S., McKay, R.G., Baim, D.S., Colucci, W.S., Fifer, M.A., Heller, G.V., Royal, H.D. and Grossman, W.: Improvement in indexes of diastolic performance in patients with congestive heart failure treated with milrinone. Circulation 70, 1030-1037 (1984) 